\title{
Opinions of university students about female genital mutilation in Sudan
}

Murat Akbas, ${ }^{1}$ Ozer Birge, ${ }^{2}$ Deniz Arslan ${ }^{3}$ and Ertugrul Gazi Ozbey ${ }^{4}$

${ }^{1}$ Manisa Celal Bayar University, Obstetrics and Gynaecology Department, Manisa, Turkey. ${ }^{2}$ Osmaniye State Hospital, Obstetrics and Gynaecology Department, Osmaniye, Turkey. ${ }^{3}$ Nyala Sudan Turkey Training and Research Hospital, Department of Gynaecology and Obstetrics, Nyala, Sudan. 4Nyala Sudan Turkey Training and Research Hospital. Department of Urology. Nyala, Sudan. (Correspondence to: Murat Akbas: drmuratakbas@yahoo. com.tr).

\section{Abstract}

Background: Female genital mutilation/cutting (FGM/C) is an illegal tradition commonly practiced in Sub-Saharan Africa and the Middle East. Despite a globalized world and developing social media, this harmful practice is currently still being implemented.

Aims: We aimed to evaluate the opinions of university students regarding FGM/C.

Methods: This descriptive study included 821 students who studied at Nyala University, Sudan, in January 2016. The students were questioned for the following: age, faculty, reasons for female circumcision, effects of female circumcision on female sexual functions and their views about the circumcision for their daughter.

Results: The rate of FGM/C among female university students was $80.1 \%$. Although $73 \%$ of the male students prefer to marry uncircumcised women, they also reported that FGM/C should be continued to be performed, and their future daughters should be circumcised (64.5\%). Female students were against FGM/C for their future daughters (77.6\%).

Conclusions: This study shows that even educated individuals demand FGM/C in spite of knowing the harm. It is therefore suggested continuing educational studies on this subject.

Keywords: Female genital mutilation, survey, university students, female circumcision, Sudan

Citation: Akbas M; Birge O; Arslan D; Ertugrul Gazi O. Opinions of university students about female genital mutilation in Sudan. East Mediterr Health J. 2019;25(4):225-229. https://doi.org/10.26719/emhj.18.033

Received: 27/07/16; accepted: 01/10/17

Copyright (C) World Health Organization (WHO) 2019. Some rights reserved. This work is available under the CC BY-NC-SA 3.o IGO license (https:// creativecommons.org/licenses/by-nc-sa/3.o/igo).

\section{Introduction}

Female genital mutilation/cutting (FGM/C) refers to all procedures that include cutting, rupturing, sewing or removing the female external genital organs in accordance with traditional rules $(1,2)$. Although it is called female circumcision in the countries where it is performed, in the medical literature due to the physical and psychological detrimental consequences this procedure is defined as mutilation $(2,3)$.

The World Health Organization (WHO) has defined four main categories of such mutilation: 1) Partial or total removal of the clitoris and/or the prepuce (clitoridectomy); 2) partial or total removal of the clitoris and the labia minora, with or without excision of the labia majora (excision);3) narrowing of the vaginal orifice with creation of a covering seal by cutting and appositioning the labia minora and/or the labia majora, with or without excision of the clitoris (infibulation); and 4) unclassified: all other harmful procedures to the female genitalia for non-medical purposes, for example, pricking, piercing, incising, scraping and cauterization (4).

According to current knowledge, more than 125 million women in the Middle East and Africa have undergone FGM/C. It is also estimated that more than 100000 ethnic immigrant women from these countries have also undergone FGM/C in Europe $(5,6)$. Each year there are two million new practices throughout the world (2). More than $90 \%$ of girls in Northern Sudan are subjected to the most severe form of FGM/C (type 3) (7).

Religion plays an important role in Sudan, with (97\%) of the country's population adhering to Islam. Although it is a cultural practice and not connected to religion, at the village level those who commit the practice offer a mix of cultural and religious reasons for the practice. It is not completely known when and for what reason FGM/C was initiated. However, it was practiced in Ancient Egypt according to examination of mummies and recorded descriptions by Ancient Greek historians (8). In many African countries, virginity is the prerequisite for a marriage; FGM/C and especially its infibulation form (Type 3) decreases sexual desire in the female and thus the probability of premarital or extramarital sexual intercourse is also decreased. According to another claim, men insist on FGM/C for marriage and this fact leads to the consolidation of such a tradition in the population over the years.

FGM/C is usually performed secretly under unhygienic conditions with the aid of non-sterile tools, without anaesthesia and using knives, razor blades, or pieces of broken glass (9-11). The three most important early complications are pain, bleeding and infection (12). The late complications are infertility, vessicovaginal fistula, menstrual problems, chronic urinary track 
infections, chronic pelvic pain, increased risk of maternal and fetal morbidity and mortality due to prolonged childbirth (13,14).

Despite all efforts and legislation to stop FGM/C, it is observed that the procedure still has a high rate of prevalence. Since university students are expected to be better educated compared to the whole population, the present study was planned to determine the opinions of university students regarding FGM/C.

\section{Methods}

This cross-sectional descriptive type study included 409 male and 412 female students who were educated in various programmes of Nyala University in the State of South Darfur, Sudan. Questionnaires were distributed to the students in the classrooms over a period of four weeks in January 2016. Three volunteer female medical students questioned the females, and three volunteer male medical students questioned the males. Questionnaires were completed during face-to-face interviews. Response rate was $88 \%$ among all students. Students were questioned on the following: age, faculty of study, reasons for FGM/C, effects of FGM/C on female sexual function, and their views about FGM/C for their possible daughter in the future. Separately, male students were questioned about the preference of a female having undergone FGM/C for marriage; while female students were questioned about whether they had already undergone FGM/C. Questionnaire forms were prepared in English and in Arabic. The content validity of the instrument was confirmed in the scale's content validity index (S-CVI), which was 0.88 . Cronbach's alpha was used to evaluate the stability and internal consistency of the tool. The overall Cronbach's alpha of this questionnaire was 0.73. Informed consent was obtained from all participants. The Nyala University Ethics Committee approved the study protocol and survey. Statistical analyses of the data were performed using the Statistical Package for the Social Sciences (SPSS) software version 22.0. and by applying the Chi square test.

\section{Results}

Age, departments of students, and genital status of female students are illustrated in Table 1. The rate of FG$\mathrm{M} / \mathrm{C}$ was $80.1 \%$, and $93 \%$ of female students underwent the procedure between 5 and 12 years of age, with a mean age of $7.97 \pm 2.49$. All participating students were Muslim. The perspectives of the two groups regarding the reasons for FGM/C were different, as shown in Table 2. Male students mostly indicated religious beliefs as the most important reason (59.7\%), while it was reported to be the least important reason by female students (10.9\%). Female students mostly indicated traditional beliefs as the most important reason for FGM/C (64.2\%). The difference in views between sexes was statistically significant $(P<$ 0.001 ).

Both groups reported that FGM/C negatively affects female sexual function (males $87.8 \%$, females $89.1 \%$ ). However, male students reported that FGM/C should be performed and their daughters should undergo the
Table 1: Age, circumcision history and academic departments of students.

\begin{tabular}{lll} 
& Males $(\mathbf{n}=\mathbf{4 0 9})$ & Females $(\mathbf{n}=\mathbf{4 1 2})$ \\
\hline Age $($ mean \pm SD) & $21.8 \pm 2.69$ & $19.5 \pm 1.95$ \\
\hline $\begin{array}{l}\text { Faculty of medicine } \\
\text { Faculty of }\end{array}$ & 33 & 55 \\
engineering & 181 & 93 \\
$\begin{array}{l}\text { Faculty of education } \\
\text { Faculty of }\end{array}$ & 12 & 55 \\
veterinarian & 118 & 95 \\
Economics & 23 & 81 \\
$\begin{array}{l}\text { Law } \\
\text { Circumcision }\end{array}$ & 42 & 33 \\
No circumcision & NA & $330(80.1 \%)$ \\
$\begin{array}{l}\text { Age at circumcision } \\
\text { (mean } \pm \text { SD) }\end{array}$ & NA & $82(19.9 \%)$ \\
\hline
\end{tabular}

NA: Not applicable

procedure in the future $(64.5 \%)$, whereas female students reported that they were against such a procedure for their daughter in the future (77.6\%). This ratio was higher among female students who had undergone FGM/C (85.1\%). The difference between sexes for this question was statistically significant $(P<0.001)$. Although male students emphasized the necessity of FGM/C their daughter, they reported that they would prefer to marry women who had not undergone FGM/C (73\%). There were also statistically significant differences between faculties and opinions about FGM/C of a future daughter. Most of the students who studied medicine $(84 \%)$ and education $(72 \%)$ were against $\mathrm{FGM} / \mathrm{C}$ of their future daughter, whereas the ratio fell in economics $(55 \%)$, law $(53 \%)$, engineering $(51 \%)$ and veterinary $(49 \%)$.

\section{Discussion}

FGM/C is a widely performed procedure in Africa. It is estimated that approximately three million girls undergo FGM/C each year (14,15). WHO, UNICEF, United Nations (UN) and many other organizations that are against the procedure have been studying its prevention procedure for many years and there are currently ongoing studies. Sudan is the first African country that banned FGM/C, with Type 3 (infibulation) outlawed in 1946, according to the Sudan penal code. In 1974, new legislation meant that FGM/C performers and those who allow it are sentenced to imprisonment for up to five years (16). However, all these efforts and legal regulations have not stopped this procedure and FGM/C is still widely performed in Sudan. The ratio of FGM/C in married Sudanese women was reported to be $89 \%$ (6). This ratio is reported to be $65 \%$ in the Darfur district, but reaches $99 \%$ in some northern states (17). In the current study the rate of FGM/C among female university students was $80.1 \%$. This result was equally as high as previously reported for community -based ratios and thus, it indicates that family social status and level of education does not affect the decision to perform FGM/C.

Male students reported religious belief as the main reason for FGM/C, whereas female students considered 
Table 2: Students' responses to questions

\begin{tabular}{|c|c|c|c|c|}
\hline Question & $\begin{array}{l}\text { Male n } \\
\text { (\%) }\end{array}$ & $\begin{array}{l}\text { Female } n \\
(\%)\end{array}$ & $\chi^{2}$ & $P$ \\
\hline $\begin{array}{l}\text { What do you think is } \\
\text { the reason for female } \\
\text { circumcision? }\end{array}$ & & & 243.365 & $<0.001$ \\
\hline Religion & $244(59.7)$ & $45(10.9)$ & & \\
\hline Traditions & $101(23.7)$ & $264(64.2)$ & & \\
\hline Social pressure & $59(14.4)$ & $57(13.9)$ & & \\
\hline Did not answer & $5(1.2)$ & $45(10.9)$ & & \\
\hline $\begin{array}{l}\text { How does } \\
\text { circumcision affect } \\
\text { female sex life? }\end{array}$ & & & 4.043 & 0.257 \\
\hline Negatively & $359(87.8)$ & $366(89.1)$ & & \\
\hline Positively & $31(7.6)$ & $19(4.6)$ & & \\
\hline Does not affect & $13(3.2)$ & $17(4.1)$ & & \\
\hline Did not answer & $6(1.5)$ & $9(2.2)$ & & \\
\hline $\begin{array}{l}\text { Should your daughter } \\
\text { be circumcised in the } \\
\text { future? }\end{array}$ & & & 149.638 & $<0.001$ \\
\hline Yes & $264(64.5)$ & $92(22.4)$ & & \\
\hline No & $145(35.5)$ & $319(77.6)$ & & \\
\hline \multicolumn{5}{|l|}{$\begin{array}{l}\text { Do you prefer a } \\
\text { circumcised spouse? }\end{array}$} \\
\hline Yes & $60(14.7)$ & NA & & \\
\hline No & $299(73)$ & NA & & \\
\hline Not important & $50(12.3)$ & NA & & \\
\hline
\end{tabular}

traditional beliefs to be the most important factor. However, many previous studies indicate that FGM/C is performed at high rates not only in Islamic countries but also in populations with different religious beliefs and in African populations that have no religious beliefs $(18,19)$. It is also known that Islam's holy book, the Quran, does not have any mention in regard to the practice. Islamic scholars disagree on FGM/C; some say that no obligatory rules exist while others refer to the mention of female FGM/C in the Hadiths (sayings, actions and approvals of Islam's Prophet Muhammad). The part of the Quran cited as evidence in support of FGM/C is the same justification for male circumcision, which is confirmed from the way of life of the Prophet Muhammad. There is nothing to prove that females underwent FGM/C during their lifetime in the Islamic period and $\mathrm{FGM} / \mathrm{C}$ is a cultural practice in communities that observe it, and it is wrong to associate Islam with such a harmful practice (20). It can therefore be understood from the responses of male students that inaccurate beliefs were present in regard to this subject. The opinions of female students about the reasons for FGM/C were similar to a previous study in which participants were selected randomly from those who attended a hospital (21).

The main reason for FGM/C is the suppression of female sexuality in order to uphold the insistence for virginity, family honour and the belief that males hold a preference for women having undergone FGM/C for marriage. However, in the current study $73 \%$ of male students reported that they would prefer woman who had not undergone FGM/C for marriage. As a result, we can conclude that although male students were aware of the harmful effects of FGM/C on female sexual health, they could not exercise free will in this matter due to social pressure.

A substantial proportion of women subjected to FGM/C experience sexual dysfunction and the anatomical extent of FGM/C is related to its severity (22). In our study we found that $87.8 \%$ of male students and $89.1 \%$ of female students replied that FGM/C negatively affects the female's sex life. However, $64.5 \%$ of male students reported that they would have their daughters undergo FGM/C in the future; this is a self-contradicting result. Male students wished this procedure to be performed even though they were aware of its associated harm. Social pressure and conventions still play a very powerful role for families in Sudan. Some Sudanese people hold the belief that women who have not undergone FGM/C exhibit continual extreme sexual desire and run a high risk of being unfaithful to their husbands. As a result, such girls could be targets for abuse in their schools and social environments. Females that have not undertone FGM/C are often teased and called 'ghalfa', a term that refers to a promiscuous woman. Thus, it is considered that a woman will only be faithful if she has undergone FGM/C (6).

While attempting to achieve the presumed benefit a reduced libido, the procedure has a negative impact on a woman's overall sexual life. FGM/C deprives women of the ability to achieve sexual satisfaction and denies them their right to sexual health, sexual pleasure and the achievement of full psychophysical well-being (23). In order to protect their daughters from sexual abuse and with concern for their virginity before marriage, families choose to have their daughters undergo FGM/C. This persists despite the high level of awareness of the negative health effects of FGM/C that were recorded in the educated population. Our study shows that education did not overcome these beliefs and harmful cultural traditions. The majority of students in medicine and education declared they would not allow FGM/C of their future daughter, while students studying engineering and economics showed less negativity about the procedure and this could be due to ignorance about the subject. It is also noteworthy that nearly half of law and veterinary students did not oppose the FGM/C; it was expected the majority of such students would be against FGM/C because of their affiliation with jurisprudence and health sciences. This result implies that relevant education should be given before university.

Sudan is the first African country to put in place laws against FGM/C. One limitation of our study was that the 
awareness of such legislation among students was not investigated. Additional studies are needed in order to evaluate this. A second limitation of our study is that we did not assess female students' experience with FGM/C and how this may have affected their response to the questionnaire.

\section{Conclusion}

FGM/C is a procedure that negatively affects women's sexual life and ability to achieve sexual satisfaction. It is accepted as an assault on the human rights of women by
WHO. However, it is still currently performed in quite high rates, as also determined in this study. It is clear that beliefs and traditions play a prominent role in this procedure, since even educated university students demand it to be performed in spite of knowing the harm. This indicates a need to develop effective strategies to increase knowledge toward FGM/C at school level. It is therefore concluded that educational studies on this subject and studies on awareness of legislation must be continued.

Funding: None.

Competing interests: None declared.

\section{Opinion des étudiants concernant les mutilations sexuelles féminines au Soudan Résumé}

Contexte : Les mutilations sexuelles féminines/l'excision constituent une tradition illégale dont la pratique est courante en Afrique subsaharienne et au Moyen-Orient. En dépit de la mondialisation et du développement des médias sociaux, cette pratique néfaste est toujours en cours de nos jours.

Objectifs : Notre objectif consistait à évaluer l'opinion des étudiants de l'université concernant les mutilations sexuelles féminines/l'excision.

Méthodes : La présente étude descriptive a été effectuée auprès de 821 étudiants inscrits à l'Université de Nyala (Soudan), en janvier 2016. Les étudiants ont été interrogés sur les points suivants : âge, faculté, raisons justifiant l'excision, conséquences de cette mutilation sur les fonctions sexuelles de la femme et leur opinion concernant cette pratique pour leurs filles.

Résultats : Parmi les étudiantes, le taux de mutilations sexuelles féminines/de l'excision était de 80,1 \%. Bien que 73\% des étudiants de sexe masculin déclarent préférer se marier avec des femmes non excisées, ils affirment également que la pratique des mutilations sexuelles féminines devrait être perpétuée et que leurs futures filles devraient être excisées (64,5\%). Les étudiantes se prononçaient contre la pratique des mutilations sexuelles/de l'excision pour leurs futures filles (77,6\%).

Conclusion: Cette étude montre que même les individus éduqués exigent la pratique des mutilations sexuelles féminines/de l'excision, bien qu'ils en connaissent la dangerosité. Nous recommandons donc de poursuivre les études à visée éducative sur ce sujet.

$$
\begin{aligned}
& \text { آراء طلاب الجامعة حول تشويه الأعضاء التناسلية للإناث (ختان الإناث) في السودان }
\end{aligned}
$$

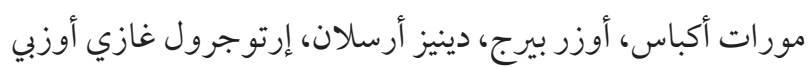

$$
\begin{aligned}
& \text { الخلاصة }
\end{aligned}
$$

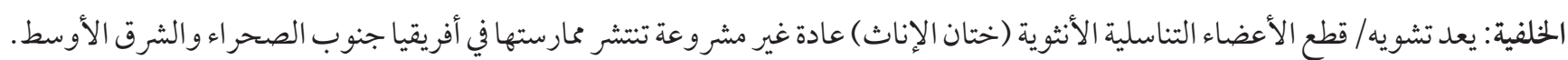

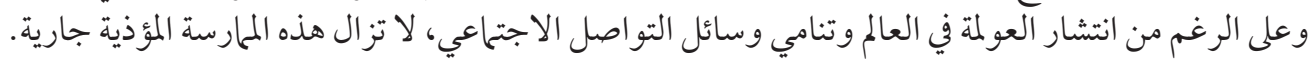$$
\text { الأهداف: هدفنا إلى تقييم آراء طلاب الجامعة حول تشويه/ قطع الأعضاء التناسلية الأنثوية (ختان الإناث). }
$$

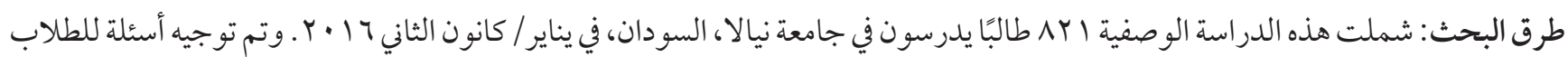

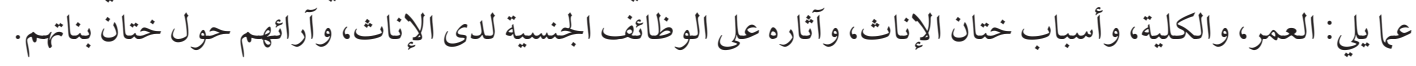

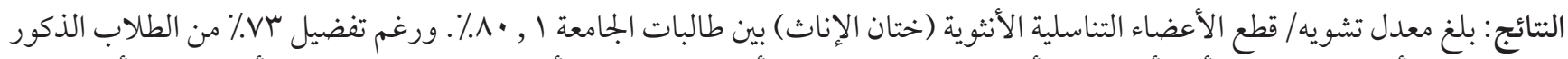

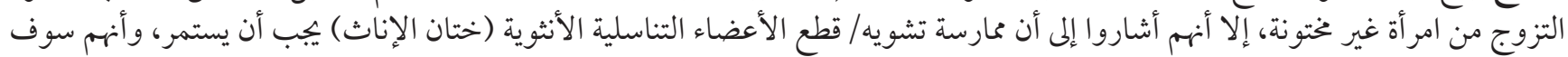

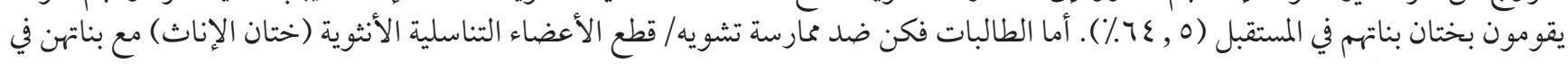

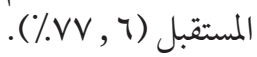

الاستنتاجات: تؤ كد هذه الدر اسة أنه حتى الأفر اد المتعلمين يطالبون باستمرار تشويه/ قطع الأعضاء التناسلية الأنثوية (ختان الإناث) رغو رغم معرفتهم

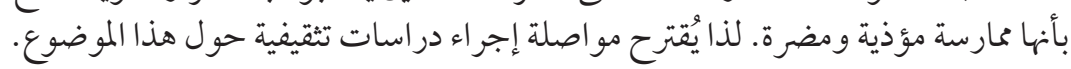




\section{References}

1. Davis RM, Genel M, Howe JP, Karlan MS, Kennedy WR, Numann PJ, et al. Female genital mutilation/cutting. JAMA. 1995;274(21):1714-6. http://dx.doi.org/10.1001/jama.1995.03530210068033

2. Kiragu K. Female genital mutilation: A reproductive health concern. Population Reports Supplement - Series J. 1995 ; No.41: 25-30.

3. Black JA, Debelle GD. Female genital mutilation in Britain. BMJ. 1995;310(6994):1590-2. http://dx.doi.org/10.1136/bmj.310.6994.1590

4. Eliminating Female genital mutilation/cutting: An interagency statement OHCHR, UNAIDS, UNDP, UNECA, UNESCO, UNFPA, UNHCR, UNICEF, UNIFEM, WHO. Geneva: World Health Organization; 2008.

5. ACOG Committee Opinion. Female genital mutilation/cutting. Int J Gynaecol Obstet. 1995;49(2):209.

6. Female genital mutilation/cutting/Cutting: a statistical overview and exploration of the dynamics of change. New York: UNICEF; 2013.

7. Female genital mutilation/cutting in Sudan and Somalia. Oslo: Landinfo, Country of Origin Information Centre; 2008.

8. Kouba LJ, Muasher J. Female circumcision in Africa: an overview. Afr Stud Rev. 1985;28(1):95-110. http://dx.doi.org/10.2307/524569

9. International Medical Advisory Panel (IMAP) statement on Female genital mutilation/cutting. London. International Planned Parenthood Federation. 1991.

10. Kandil M. Female circumcision: Limiting the harm [version 2; referees: 2 approved, 1 approved with reservations]. F10ooResearch 2012, 1:23 http://dx.doi.org/10.12688/f100oresearch.1-23.v2)

11. Shah G, Susan L, Furcroy J. Female circumcision: history, medical and psychological complications and initiatives to eradicate this practice. Can J Urol. 2009;16(2):4576-9.

12. Ali AA. Knowledge and attitudes of Female genital mutilation/cutting among midwives in Eastern Sudan. Reprod Health. 2012;9(23). https://doi.org/10.1186/1742-4755-9-23

13. Almroth L, Elmusharaf S, El Hadi N, Obeid A, El Sheikh MAA, Elfadil SM, et al. Primary infertility after genital mutilation in girlhood in Sudan: a case-control study. Lancet. 2005;366(9483):385-91. http://dx.doi.org/10.1016/So140-6736(05)67023-7

14. Banks E, Meirik O, Farley T, Akande O, Bathija H, Ali M. Female genital mutilation and obstetric outcome: WHO collaborative prospective study in six African countries. Lancet. 2006;367(9525):1835-41. http://dx.doi.org/10.1016/So140-6736(06)68805-3

15. Isman E, Warsame A, Johansson A, Fried S, Berggren V. Midwives' experiences in providing care and counselling to women with female genital mutilation (FGM) related problems. Obstetrics and Gynecology International. 2013. Article ID 785148, 9 pages.

16. Laws of the Sudan. Volume 9. Provision. 1974-1975;284A:91.

17. Sudan Demographic and Health Survey. Maryland: Department of Statistics, Ministry of Economic and National Planning; 1990.

18. Chelala C. A critical move against female genital mutilation/cutting. Populi. 1998;25(1):13-5.

19. Grisaru N, Lezer S, Belmaker RH. Ritual female genital surgery among Ethiopian Jew. Arch Sex Behav. 1997;26(2):211-5. http:// dx.doi.org/10.1023/A:1024562512475

20. Asmani IL, Abdi MS. De-linking Female genital mutilation/cutting from Islam. Washington: Population Council; 2008.

21. Birge O. Current survey of female genital mutilation in Darfur. IJIRR 2016;03:1735-8.

22. Rouzi AA, Berg RC, Sahly N, Alkafy S, Alzaban F, Abduljabbar H. Effects of female genital mutilation/cutting on the sexual function of Sudanese women: a cross-sectional study. Am J Obstet Gynecol. 2017;217(1):62.e1-e6. http://dx.doi.org/10.1016/j. ajog.2017.02.044

23. Abdel-Azim S. Psychosocial and sexual aspects of female circumcision. Afr J Urol. 2013;19(3):141-2. http://dx.doi.org/10.1016/j. afju.2012.12.005 